\title{
Ralph Ellsworth and The University of Iowa Libraries
}

For 40 years after President George MacLean proposed in 1900 to elevate The University of Iowa to a place among the major academic institutions of the Midwest, the continuing lack of a library building served as a constant reminder of the unrealized aspirations of the University's supporters. Following the destruction of North Hall by fire in 1897, such library books as could be salvaged were of necessity dispersed about the campus in departmental libraries. The Pentacrest building later named Macbride Hall had been intended to house the science departments, but MacLean commandeered the circular core of the building as a "temporary" home for the library, much to the annoyance of the scientists. The library remained there for nearly half a century. Additional space for a reserved book reading room and periodicals was found in the Old Armory at the foot of Washington Street.

When Virgil Hancher became president in 1940, he made the erection of a library building a major objective of his administration. Within six months of his inauguration, he secured from the legislature an appropriation of $\$ 300,000$ with which to construct the first unit of the long-awaited building. World War II then intervened, and when Hancher retired in 1964 after 24 years in office, the library was still less than half completed. ${ }^{1}$

The president had moved promptly to appoint a strong library planning committee of which Elmer T. Peterson of the College of Education was the moving spirit. The committee was

\footnotetext{
${ }^{1}$ The University of Iowa Libraries, Annual Report, 1940-41.
} 
determined to strengthen the educational functions of the library, both by securing a senior library staff with academic qualifications and by nurturing a closer integration of library services with instructional needs. The committee found in the University of Colorado librarian, Ralph E. Ellsworth, a man whose thinking paralleled its own. Ellsworth had recently planned and built a library at Colorado designed to function as a teaching instrument. Three specialized reading rooms with open shelves for books, periodicals, and reference works served the needs of upperclass undergraduate and graduate students in the sciences, social sciences, and humanities, respectively. Each academic department assigned instructors or assistants to work with students in the library, while the library itself appointed staff members with appropriate subject matter as well as technical library training. ${ }^{2}$ Ellsworth also had innovative ideas about library construction. In place of the traditional monumental library building with its fixed allocation of spaces for books, readers, and services, Ellsworth proposed a strictly functional building of the commercial type based upon a rectangular spatial unit or module of ten by twenty feet, with artificial light and forced ventilation. Any number of modules could be assembled to constitute a building of the desired shape and size. Movable partitions would permit the rearrangement of functional spaces as needs might change with time. At Iowa, where the library was to be built in four installments over a long period of years entailing extensive reallocations of space, the modular principle proved to be a godsend. Unfortunately, W. T. Proudfoot, the architect of the Pentacrest buildings, was no longer alive to take up the aesthetic challenge of the new functionalism, and the first unit of the library turned out to be an eyesore. ${ }^{3}$

The Iowa committee enthusiastically endorsed Ellsworth's

\footnotetext{
${ }^{2}$ Ralph Ellsworth, University of Colorado Studies, Nov., 1941, p. 38.

${ }^{3}$ Ellsworth to Hancher, Feb. 25, June 16, 1944, Hancher Presidential Correspondence (hereafter HPC), The University of Iowa Archives, 1943-44, \#106. K. Keffer to Library Building Committee, June 16, 1944, ibid. A. M. Githens to F. W. Ambrose, April 16, 1944, ibid.
} 
principles, which were incorporated in its own plan for the Library and Instructional Center, drafted by Peterson. The prime objective was to integrate the educational program with the library facilities in order to bring student, book, and professor into a vital relationship. Prominent in the thinking of the planners was the analogy of the laboratory where the student confronted his problem directly. In addition to stack space for 1,250,000 volumes, three divisional reading rooms, or "instructional laboratories," were planned for lower division undergraduates, for the School of Letters (languages and literature) and for the social studies. Each reading room would accommodate 160 readers and house some 15,000 volumes. Conference rooms, small classrooms, carrels for graduate students, and offices for faculty and staff would be located nearby. Benjamin Shambaugh's popular Campus Course provided something of a model. That course had been offered in a large room in Schaeffer Hall, which combined the informality of a library browsing room with the seating of a lecture hall. The committee hoped to commemorate Shambaugh's achievements and possibly perpetuate the Campus Course as well by making provision for a large auditorium where courses making appropriate use of library materials might meet. ${ }^{4}$

Colorado had embraced Ellsworth's educational theories, but it had refused to build a modular library. The Iowa committee assured him that if he would come to the University as director of libraries it would firmly support both his educational ideas and his plan of construction. He indicated that he would accept an Iowa offer subject to three conditions: first, that as director he would have the rank of dean with the administrative relationships necessary to execute his responsibilities; second, that his role be recognized as that of a "library statesman" and

\footnotetext{
${ }^{4}$ Shambaugh's course offered a comprehensive survey of human culture from the Big Bang to the Big Depression. The Department of Political Science had found it impossible to provide a successor who could conduct the course with Shambaugh's showmanship and had abandoned it. "The Proposed University of Iowa Library and Instructional Center," July 15, 1942, HPC 1942-43, \#106.
} 
not merely a technician; and, third, that he be allowed to use his summers as he thought proper. A prudent executivewhich Hancher certainly was-might well have requested a clarification of each of these conditions, but in any event the committee chairman, history department head W. T. Root, reported that they were acceptable to Hancher, whose offer of appointment was made and accepted in September, 1943.5

Planning the new building and refining his ideas about the role of the library in the educational program fully occupied Ellsworth during the war and immediate postwar years when defense and other pressing needs forced delays in the construction program. Obstacles and frustration marked the project from the beginning. The board of education had selected an architectural firm for political reasons, ignoring the objections of the Planning Committee. The senior member of the firm stubbornly refused to employ the modular method of construction. It was only after much wrangling and costly delays that a junior member took charge and proceeded with modular construction. The original allocation of $\$ 300,000$ was a mere pittance in terms of postwar prices, and three additional appropriations totaling just under $\$ 2$ million were necessary to build the first unit. ${ }^{6}$ It was not until 1949 that ground was broken for the new building. In the meanwhile, Ellsworth was perfecting his plans for the library as a teaching instrument.

His ideas supplemented and amplified those of the committee. Despite its superficiality, he continued to emphasize the analogy of the properly conducted library to the scientific laboratory. Progress in science, he believed, had been achieved because of the fruitful meeting of professor and student in the laboratory. Comparable success would be achieved in the humanities and social sciences when library facilities permitted student and teacher to work together in the presence of their

\footnotetext{
${ }^{5}$ Ellsworth to author, Nov. 18, 1987. Ellsworth to Hancher, April 16, 1945, HPC 1944-45, \#108. Hancher to Ellsworth, Sept. 21, 1943, HPC 1943-44, \#106. Ellsworth to H. Davis, Dec. 1, 1948, HPC 1948-49, \#114.

${ }^{6}$ F. G. Higbee, "The Construction of the University Library," Nov. 6, 1952, HPC 1952-53, \#107.
} 
study and research materials. The sterile distinction between classroom learning and library research would be submerged in a vital and creative joint experience. Professional library staff members who would be fully qualified in the relevant subject matter areas would work closely with the students. Each of these specialists would teach as well as work informally as research advisers. As Ellsworth put it: "The creation of a natural working relationship in which the instructor and the student use the library as a laboratory is thus the first foundation stone of the Iowa program." 7 The laboratory analogy served to obscure the fact that one form of learning experience would be substituted for another. It was a proposal undoubtedly congenial to Hancher and to Peterson, but it remained to be seen whether it would appeal to the liberal arts faculty, which was committed to the conventional classroom method of instruction.

Special facilities were to be provided for the newly adopted "core" curriculum of undergraduate studies. The College Library (later renamed the Heritage Library), a large area on the main floor with space for 700 readers, but broken up into small spaces to provide the "atmosphere of a fine home library," would house the materials to be used in the core courses. These materials would include not only books but also pictures, maps, cultural artifacts, slides, recordings, and audiovisual materials, and would be organized in eight chronological periods. These arrangements appeared to presuppose that the library staff would have a substantial voice in determining the content and methods of teaching the core courses. In the Shambaugh Auditorium adjacent to the College Library, a lecture series on contemporary problems would be offered by a lecturer selected by Ellsworth. The academic counseling service would also be located in the library. There would be seminar rooms for graduate courses as well as graduate student and faculty lounges. The basement would contain a bookstore,

\footnotetext{
${ }^{7}$ [Ralph E. Ellsworth] The Library as a Teaching Instrument (Iowa City: State University of Iowa, 1945).
} 
newspaper room, and possibly a soda fountain. ${ }^{8}$

More conventional library functions that had previously been neglected were to be vigorously promoted. Now that appropriate facilities would be available, plans were made for the collection of rare books and manuscripts. Deposits of the papers of prominent Iowans were solicited, and an Iowa authors library was assembled. A collection of "right wing" political materials was begun. These and other collecting activities were to be supported by the organization of a Friends of the Library group, a membership organization composed of patrons interested in enriching the library's holdings of rare and valuable materials. The model for the Friends was found in similar organizations at the private universities of the eastern seaboard, where wealthy alumni and other patrons made generous gifts to their respective institutions. It quickly became apparent that The University of Iowa lacked a comparable constituency of bibliophiles. Ellsworth too readily became discouraged, and the Friends organization was allowed to lapse. It remained for his successor to revive it on the assumption that an ongoing group, however modest its accomplishments, could eventually demonstrate its value to the University, which it is now doing.

As the librarian unfolded his ambitious plans, it became apparent why he had stipulated that he have a dean's status, for he was determined to be an educational officer with an important role in the instructional program. His criticism of the sterility of traditional classroom lecturing, if taken to heart, would have a significant effect on the University. Over the collegiate faculties he would have only the power of persuasion, although he reported, perhaps too optimistically, that the faculty in political science, English, economics, sociology, and history had enthusiastically approved his ideas. ${ }^{9}$ He would of course have direct control over those of his own staff who

\footnotetext{
${ }^{8}$ R. E. Ellsworth, "Some Notes on the Proposed Library Building at The University of Iowa," HPC 1944-45, \#108. R.E. Ellsworth to Lewis Brown, Nov. 30, 1944, ibid.

${ }^{9}$ Ellsworth to Lewis Brown, Feb. 1, 1945, ibid.
} 
might be engaged in teaching. Nevertheless, his position was an awkward one. Following the departure in 1948 of the liberal arts dean, Earl McGrath, Ellsworth hoped to be appointed dean, a position which went to Dewey B. Stuit. Although Hancher approved of Ellsworth's ideas and gave him encouragement, the president was unwilling to intervene in college affairs. Within the faculty, the principal support for Ellsworth's educational program came from the College of Education. Peterson, later dean of that college, had drafted the original proposals of the Library Planning Committee. Harry Newburn, who had come to the liberal arts deanship from education, was a firm supporter. McGrath, who had succeeded Newburn, and was also an educationist, was sympathetic. Stuit, on the other hand, was a psychologist and the popular choice of the liberal arts faculty. He was determined to keep control of liberal arts education, and his relations with Ellsworth were not cordial.

The projected library was to be a large building with 427,188 square feet of floor space. The first unit, consisting of three floors fronting on Washington Street, contained only 137,532 square feet, less than a third of the projected total. As soon as it was completed and occupied in 1951, Ellsworth began to press Hancher for funds with which to add a second unit. The president responded that there were other urgent needs; the library would have to wait its turn. In addition to its library functions, Ellsworth and the Planning Committee had hoped to locate the offices of all of the social science and humanities departments in the new building. But without space in the first unit for some 60,000 volumes of the existing collection, it was obviously impossible to implement their ambitious plans. Only the geography and philosophy departments were housed in the new building. When Ellsworth complained that his educational program would be jeopardized by lack of space, Hancher assured him that his plans were not to be abandoned; space would be saved for the teaching function. Nevertheless, as the 
years passed without further funding, Ellsworth became increasingly pessimistic. ${ }^{10}$

An integral part of the plan to use the library as a teaching instrument had entailed the conferring of faculty status on those professional librarians involved in teaching. Ellsworth had not received a specific commitment from Hancher, but he apparently took it for granted that such appointments would be made. When in 1950 he appealed to the president on the matter, he was told that it would be "held in abeyance." $\mathrm{He}$ was referred to the Faculty Council, to which he reported that 32 of the 73 library staff members were professionally qualified for faculty status. He assured the council that although these people were qualified for teaching appointments in the academic departments, he preferred to have them on the library staff. Council members were critical of the plan, and voted against it. Hancher was content to allow this representative faculty group to decide the matter. It was a bitter defeat for Ellsworth. Following his departure, his successor, Leslie Dunlap, again raised the issue of faculty status, but without this time proposing teaching duties. Again the council turned down the proposal, suggesting that titles "comparable" to those of the teaching faculty be employed. Hancher aptly pointed out that since there were no comparable titles he interpreted the council's suggestion to be a veto. By 1953, Ellsworth concluded that space limitations and policy disagreements made it futile to continue to press for his program. ${ }^{11}$

Ellsworth's third condition of appointment had been that he be permitted to use his summers as he saw fit. His Colorado mountain cabin was a valued place for relaxation and uninter-

\footnotetext{
${ }^{10}$ Ellsworth to Hancher, July 29, 1948, HPC 1948-49, \#114. Ellsworth to Hancher, Jan. 17, 1951, HPC 1950-51, \#105. Hancher to H. Davis, Mar. 9, 1951, ibid.

${ }^{11}$ Ellsworth to Hancher, July 5, 1950, HPC 1950-51, \#105. Hancher to Ellsworth, July 12, 1950, ibid. University Faculty Council minutes, April 10, 17, May 8, 1951, Folder, "University Council, 1948-51," The University of Iowa Archives. Council minutes, April 14, 29, 1959, Folder, "Faculty Council, 7/1/58-6/30/59." Hancher to Willard Boyd, May 18, 1959, ibid. Ellsworth to Hancher, May 16, 1953, HPC 1952-53,\#107.
} 
rupted thinking. He had requested the standard faculty ninemonth rather than the eleven-month appointment held by administrative officers. He had been assured by the Library Planning Committee that his terms were acceptable to Hancher, but it eventually transpired that the committee chairman, W. T. Root, had not in fact mentioned the conditions to the president. When certain administrators, presumably jealous of his extended "vacation," complained, Ellsworth was called to account by the administrative dean, Allin Dakin, and an unhappy exchange of communications revealed something of the tensions within the administration. After considerable vacillation, Hancher agreed to Ellsworth's terms and assured him of his high regard. Coming on top of lagging construction and the frustration of his educational objectives, this unhappy episode further alienated him from the University. He welcomed an opportunity to return to the University of Colorado, leaving a library which was innovative in form but conventional in function. Small additions to the building were completed in 1961 and in 1965. It was not until 1972 that the library was completed with a final addition equal in size to the first three units. The extensive rearrangement of functions in the completed building was facilitated by the flexibility of the modular principle, a fitting monument to the departed planner. ${ }^{12}$

\footnotetext{
${ }^{12}$ Ellsworth to Hancher, April 16, 1945, HPC 1944-45, \#108. Hancher to Ellsworth, April 20, 1945, ibid. Ellsworth to Dakin, April 1949, HPC 1948-49, \#114. Dakin to Ellsworth, April 18, 1949, ibid. Hancher to Ellsworth, Nov. 15, 1949, HPC 1949-50, \#112. Ellsworth to Hancher, Nov. 16, 1949, ibid. Hancher to Ellsworth, Dec. 20, 1949, ibid.
} 